\title{
Effect of Various Doses Gamma-radiation on Phenotypic and Molecular Characteristics of Two Egyptian Soybean Varieties
}

\author{
R.M. Gaafar*, A.R.Elshanshory, M. Hamouda and R. Diab \\ Botany Department, Faculty of Science, Tanta University, \\ 31527 Tanta, Egypt.
}

\begin{abstract}
TWO Egyptian soybeans varieties, Giza111 and Crawford were selected for the current study. Their seeds were exposed to three doses of gamma-radiation 150, 200, and 250 Gy in order to study their mutagenic effects in the treated seeds and two following generations at various levels. In the first generation (M1), two doses (150 and 200 Gy) were the most effective in enhancement of some agronomic traits like number of stem branches, number of pods per plant, number of seeds per pod and weight of 100 seeds and crop yield. Analysis of protein profiles using SDS-PAGE showed variation among the treatments in each variety, where a total of 35 protein bands were recorded. Three of which were unique bands, one unique band of size $37 \mathrm{kDa}$ was found in the treated seeds before germination (M0) in Crawford at 250 Gy treatment. The other two unique bands (102 and $162 \mathrm{kDa}$ ) were found in M2 generation in Crawford at 150 Gy and Giza111 at $200 \mathrm{~Gy}$, respectively. ISSR analysis using five primers gave a total 45,38 and 28 ISSR bands in M0, M1 and M2, respectively; 4 of which were unique bands. The primer HB14 amplified 6 DNA bands, 2 were unique bands ( $895 \& 1050 \mathrm{bp}$ ), both in M1 generation of Giza111 at $150 \mathrm{~Gy}$, while primer 844 and 862 amplified only one unique band both found in M0 Giza111 control. They have a molecular size of 888 and $900 \mathrm{bp}$, respectively. Although, UBC-827 amplified the highest number of bands (7) no unique bands were found.
\end{abstract}

Keywords: Glycine max L., Gamma-radiation, SDS-PAGE, ISSR, polymorphism.

Soybean (Glycine max L.) integrates in one crop both the dominant world supply of edible vegetable oil, and the dominant supply of high-protein feed supplements for livestock. Its seed residues and derivatives have a substantial economic importance in a wide range of industrial, food, pharmaceutical, and agricultural products (Smith and Huyser, 1987). In addition, soybean protein is rich in the valuable amino acid lysine $(5 \%)$ in which most of the cereals are deficient. Moreover, it contains a good quantity of minerals, salts and vitamins. Soybean's oil has been used in Egypt since year 1976, its oil extraction ratio is about $20.5 \%$. Furthermore, soybean is an essential source of protein in the animal and poultry feed (Çelik et al., 2014).

E-mail: redagaafar@science.tanta.edu.eg or redagaafar@gmail.com 
Mutations, both spontaneous and induced have been highly successful in changing the fatty acid composition of several oil seed crops. Three reasons have been given for attempts in changing seed oil quality by means of single gene mutations being exceptionally successful. Various soybean mutant lines were identified using mutation, which possessed many desirable traits like habit, low linolenic, high oleic content and resistance to pod shattering (Rahman et al., 1995). In addition, mutational breeding is thought to be as a source of increasing genetic variability and particular improvement could be conferred without importantly changing its satisfactory phenotype (Mudibu et al., 2011; Ambavane et al., 2015). In plants, induction of genetic and morphological variabilities, using induced mutation, has been found as the most efficient method. Several studies have shown that exposure to gamma-radiations can have stimulatory effects on specific morphological parameters and can increase the yield of plants and their resistance to drought (Yu et al., 2007; Melki and Dahmani, 2009; Hanafiah et al., 2010; Badr et al., 2014a and b; Ariraman et al., 2016 and Gaafar et al., 2016). One of the most successful mutagenic agents is radiation, which induced mutation breeding in various crops and ornamental plants (Schum, 2003). Radiation represented excellent means of stimulating the expression of recessive genes, thus inducing new genetic variation (Song and Kang, 2003).

The effectiveness of gamma radiation in improving plant growth, seed quality, cooking time and physiological processes is highly related to the level of doses used (Lima et al., 2011; Hegazi and Hamideldin, 2010) showed that gamma radiation at $0.4 \mathrm{kGy}$ showed the highest improvement in okra plant growth and seed yield when compared to $0.3 \mathrm{kGy}$ and $0.5 \mathrm{kGy}$. However, the application of gamma radiation in developing high grain yield soybean varieties was limited (Lima et al., 2011). Addai and Safo-Kantanka (2006) subjected three soybean genotypes to $(0,50,100,150,200,250$ and $300 \mathrm{~Gy})$ of gamma radiation. It has been found that emergence percentage and seedling height have been approximately reduced to $50 \%$ by 250 Gy dose compared to the control $(0$ Gy). Therefore, it was considered as the appropriate dose for induced mutation in the used genotypes. Variations in M1 generation, though less important in view of obtaining stable gene mutations, are often considered as indicator in measuring efficiency of the mutagens (Plesnik, 1993). Meanwhile, various studies were dealing with analysis of M2 and M3 generations of soybean induced by physical and chemical mutagens (Patil et al., 1985).

Many molecular marker systems have been routinely used to evaluate mutations and genetic variation in plants. These include SDS-PAGE protein patterns, randomly amplified polymorphic DNAs (RAPDs), amplified fragment length polymorphisms (AFLPs) and inter simple sequence repeats (ISSRs) (Atienzar and Jha, 2006). Afify and Shousha (1988) described that changes in protein subunit patterns were identified in the cultivar "Clark" using SDS-PAGE, 
depending on the dose of $\gamma$-rays, where three high molecular weight protein bands were found in soybean cultivars exposed to $\gamma$-rays. Moreover, it has been shown that radiation caused native protein aggregation, which might simply have resulted from rearrangement of the composed protein subunits. ISSR is a technique that is widely used for assessing the alteration in DNA sequences induced by mutagenic agents such as gamma rays (Mudibu et al., 2011 and Mejri et al., 2012; Hamideldin and Eid, 2015; Gaafar et al., 2016). Currently, induced mutation is widely used for introducing of genes, which control important traits and understanding the function and mode of action of such genes as well as developing improved crop varieties.

The aim of this study is to evaluate the effect of distinct doses of gamma rays on characteristics, protein profiles and ISSR polymorphism of two soybean varieties, in order to identify gamma-induced mutant lines with potentially improved agronomic characteristics.

\section{Material and Methods}

Seeds of the two soybean varieties (Giza 111 and Crawford) were obtained from the Food and Legumes Research Department, Field Crops Research Institute, Agricultural Research Center, Giza, Egypt in 2013. Dry seeds of the two soybean varieties were exposed to three different doses of gamma radiation at the Atomic Energy Center, Nasr City, Cairo, Egypt using cobalt 60 as a source of gamma-radiation. The applied doses were 150, 200, and $250 \mathrm{~Gy}$. The seeds of control samples were not exposed to gamma radiation.

\section{Morphological analysis}

In season 2014, exposed and control seeds of the two soybeans varieties were grown to maturity in the greenhouse of Botany Department, Faculty of Science, Tanta University. Forty soybean gamma-radiated seeds (treated seeds parents or M0 generation) of each dose/variety as well as controls were cultivated per line. Then after four weeks of growth, the seedlings were then thinned to 20 plants per line. Plants were irrigated every 10 to 14 days from sowing until maturity and 20 lb/acre of phosphate fertilizer was employed as a side band with the seed and at seedling and fruiting stages.

Morphological observations were carefully and continuously recorded throughout the stages of growth in order to examine the morphological variation in M1 plants compared to the control. A number of morpho-agronomic parameters were measured after six weeks from sowing. The measured criteria were seedling length $(\mathrm{cm})$, days to flowering, days to maturity, shoot length $(\mathrm{cm})$, number of branches of stem, number of pods per plant, number of seeds per pod, pod length $(\mathrm{cm})$, first germination percentage $(\%)$, seed length $(\mathrm{cm})$, 
weight of 100 seeds (gm), crop yield (no. seeds/plant), and pod shattering (\%). In addition, presence of stem appendages, leaf abnormalities, flower color, pod appendages, pod color, coat color, seed hilum color were also documented.

In season 2015, the seeds of the M1 plants were then sown and grown as explained above. In this field experiment, all morphological measurements were also recorded for the M2 plants as previously described above.

\section{Protein analysis}

Total seed proteins were extracted using $0.03 \mathrm{M}$ Tris $-\mathrm{HCl} \mathrm{pH}=8$ as an extraction buffer, $0.01 \mathrm{gm}$ of the dry seed was grinded in a mortar with pestle, then $400 \mu \mathrm{l}$ of the extraction buffer was added. The extraction was done in Eppendorf tubes over night at $4^{\circ} \mathrm{C}$. After that the tubes were centrifuged at 15000 rpm for $20 \mathrm{~min}$ at $4^{\circ} \mathrm{C}$ (Sigma $3 \mathrm{~K} 18$ Bench Top centrifuge). Main slab gel of $12 \%$ polyacrylamide $(7.5 \times 6 \times 0.1 \mathrm{~cm})$ was prepared as described by Laemmli (1970). Molecular weight marker proteins (Fermentas, Germany) run in parallel to samples were BSA (66 kDa), egg albumin (45 kDa), glyceraldehyde-3phosphate dehydrogenase $(36 \mathrm{kDa})$, carbonic anhydrase $(29 \mathrm{kDa})$, trypsinogen $(24 \mathrm{kDa})$, trypsin inhibitor $(20.1 \mathrm{kDa})$, and a-lactalbumin $(14.2 \mathrm{kDa}) .50 \mu \mathrm{l}$ of the protein extracts were applied into the PAGE gel wells. The electrophoresis was carried out at $100 \mathrm{~V}$ and $15 \mathrm{~mA}$ using power supply (DYY-12 power supply Beijing Liuyi, Germany) until the stacking gel was ended, then completed at 150 $\mathrm{V}$ and $20 \mathrm{~mA}$ in $1 \times$ running protein buffer until reached the bottom of the gel. The bands were stained overnight with coomassie brilliant blue (CBB) solution, then destained using the same solution without $\mathrm{CBB}$ until the gel background became clear.

\section{DNA extraction}

For DNA extraction, the indirect DNA extraction method (Gene JET DNA purification kit Molecular Biology, Thermo Scientific Company, Germany) was used, $0.1 \mathrm{gm}$ of dry seed were grounded and extracted with $350 \mu \mathrm{l}$ of lysis buffer A, the tubes were properly vortexed for $20 \mathrm{secs}$, and $50 \mu \mathrm{l}$ lysis buffer B was added. After that, $20 \mu \mathrm{l}$ of RNase was added and the extract was incubated in a shaking water bath at $65^{\circ} \mathrm{C}$ for $10 \mathrm{~min}$. The tubes were then vortexed and incubated on ice for $5 \mathrm{~min}$ and centrifuged at $14000 \mathrm{rpm}$ for $5 \mathrm{~min}$. The supernatants were transferred into clean Eppendorf tubes, after that $400 \mu 1$ of plant DNA binding solution and $400 \mu \mathrm{l}$ of $96 \%$ ethanol were added to the column, so the volume became $1300 \mu \mathrm{l}$, then half of the volume was loaded into the column and centrifuged at $8000 \mathrm{rpm}$ for $1 \mathrm{~min}$. and the supernatant was thrown, repeat this step for the other half, then the columns were washed with $500 \mu \mathrm{l}$ of washing buffer 1 , and centrifuged for one min. at $8000 \mathrm{rpm}$ and the supernatant was thrown. Subsequently, $500 \mu \mathrm{l}$ of washing buffer 2 was added and columns were centrifuged for $3 \mathrm{~min}$ at $14000 \mathrm{rpm}$, and the supernatant was 
thrown. Extra centrifugation step was done for $1 \mathrm{~min}$ at $14000 \mathrm{rpm}$. The DNA was eluted by adding $100 \mu$ l elution buffer, the columns were kept at room temperature for $5 \mathrm{~min}$, then centrifuged for $1 \mathrm{~min}$ at $10000 \mathrm{rpm}$. The centrifugation step was repeated two times and then the extracted DNA was stored in $-80{ }^{\circ} \mathrm{C}$ till use.

\section{ISSR amplification and electrophoresis}

In total, 12 ISSR primers (Operon Nippon EGT CO. LTD.USA), were screened for the production of polymorphic products from all samples. Only five primers showed polymorphic patterns and were selected. This was done after amplification conditions were optimized by selecting appropriate $\mathrm{MgCl}_{2}$ concentrations and anneal temperatures (Table 1).

TABLE 1. Names, sequences and annealing temperatures of the selected ISSR primers.

\begin{tabular}{llc}
\hline Primer name & \multicolumn{1}{c}{ Sequence } & Annealing temp. \\
\hline $\mathbf{8 6 2}$ & 5'-AGCAGCAGCAGCAGCAGC-3 & 57.5 \\
UBC-827 & 5'-ACACACACACACACACG-3` & 41 \\
HB10 & 5'-GAGAGAGAGAGACC-3 & 44 \\
$\mathbf{8 4 4}$ & 5'-CTCTCTCTCTCTCTCTGC-3 & 38.8 \\
HB14 & 5'-GTGTGTGTGTGTCC-3` & 44 \\
\hline
\end{tabular}

Isolated genomic DNA was used as template in the amplification reactions. A total of $25 \mu \mathrm{l}$, with $12.5 \mu \mathrm{l}$ green master mix reaction mix was prepared (NIPPON Genetics EUROPE Master mix Taq Ready Mix with Dye), $3 \mu$ primer of concentration $10 \mathrm{pmole} / \mu \mathrm{l}$. Amplification conditions were optimized using a gradient thermal cycler (Biometera Thermal Cycler, Germany). The following PCR program with following settings was used as described by Gaafar et al. (2015): an initial denaturation at $94^{\circ} \mathrm{C}$ for $4 \mathrm{~min}$., followed by 40 cycles of 45 sec. at $94^{\circ} \mathrm{C}$ for denaturation, annealing temperature, based on each primer composition, for $45 \mathrm{sec}$., and $45 \mathrm{sec}$. at $72^{\circ} \mathrm{C}$ for extension and a final extension at $72^{\circ} \mathrm{C}$ for $7 \mathrm{~min}$., and then temperature was set at $4^{\circ} \mathrm{C}$ till the removal of PCR tubes. The PCR products were separated on $1.5 \%$ agarose gel by mixing $12.5 \mu 1$ of the PCR-products of each primer with $2.5 \mu \mathrm{l}$ of loading buffer and loading into the agarose wells. Gel electrophoresis was performed in $0.5 \times$ TAE buffer at $70 \mathrm{~V}$ for $1 \mathrm{hr}$ ISSR gels were visualized using UVP gel documentation system (UVP, UK) and photographed under UV light. The size of each band was estimated using 100 bp DNA ladder (Fermentas, Germany) as a standard marker. Because ISSRs are multi-loci and dominant markers, the amplified polymorphic DNA fragments were scored as binary presence (1) or absence (0), and the percentage of polymorphic fragments was used to evaluate the genetic variability and mutations in the two used soybean varieties. 
Statistical analysis

Statistical presentation and analysis of the quantitative traits was conducted by calculating the mean, standard deviation (SD) and analysis of variance (ANOVA) tests using the COSTAT analysis of variance (ANOVA). One-way test was used to compare $\mathrm{P}$ and LSD values among different varieties and gamma doses in the same criteria of the quantitative morphological measurements.

\section{Results and Discussion}

Morphological analysis

At morphological level, the 150 and 200 Gy doses were the most effective in increasing some of these morphological characters from M1 to M2 like germination percentage, shoot length, stem branching, pod shattering, crop yield (no. of seeds/plant), number of pods/plant, pod length, number of seeds/pod and weight of 100 seeds (Table $2 \mathrm{a}$ and $2 \mathrm{~b}$ ).

TABLE 2a. Mean of the quantitative morphological characteristics of M1 generation of the two soybean varieties (Giza111 and Crawford) after exposure to different doses of gamma-irradiation.

\begin{tabular}{|c|c|c|c|c|c|c|c|c|}
\hline \multicolumn{9}{|c|}{ Soybean variety } \\
\hline \multirow[b]{2}{*}{ Character } & \multicolumn{4}{|c|}{ Giza111 } & \multicolumn{4}{|c|}{ Crawford } \\
\hline & Control & $\begin{array}{r}150 \\
\text { Gray } \\
\end{array}$ & $\begin{array}{c}200 \\
\text { Gray }\end{array}$ & $\begin{array}{c}250 \\
\text { Gray }\end{array}$ & Control & $\begin{array}{r}150 \\
\text { Gray }\end{array}$ & $\begin{array}{r}200 \\
\text { Gray } \\
\end{array}$ & $\begin{array}{c}250 \\
\text { Gray }\end{array}$ \\
\hline Days to flowering & 30 & 26 & 35 & 35 & 31 & 31 & 32 & 80 \\
\hline Days to maturity & 55 & 64 & 80 & 80 & 50 & 60 & 76 & 109 \\
\hline Germination (\%) & 100 & 75 & 25 & 67.5 & 50 & 47.5 & 15 & 10 \\
\hline Pod shattering $(\%)$ & 1.68 & 9.1 & 6.8 & 1.2 & 2.9 & 2.8 & 0 & 0 \\
\hline $\begin{array}{l}\text { Weight of } 100 \\
\text { seeds }(\mathrm{g})\end{array}$ & 15 & 14.5 & 13 & 12.5 & 13 & 10.14 & 1.85 & 0.8 \\
\hline $\begin{array}{l}\text { No. of seeds per } \\
\text { plant }\end{array}$ & 3.26 & 1.83 & 2.42 & 1.7 & 2.86 & 1.96 & 1.3 & 1.6 \\
\hline $\begin{array}{l}\text { No. of pods per } \\
\text { plant }\end{array}$ & 87 & 47 & 27 & 31 & 74 & 25 & 6 & 2.5 \\
\hline Days to flowering & 30 & 26 & 35 & 35 & 31 & 31 & 32 & 80 \\
\hline Days to maturity & 55 & 64 & 80 & 80 & 50 & 60 & 76 & 109 \\
\hline
\end{tabular}

Egypt. J. Bot. 57, No. 1 (2017) 
TABLE 2b. Mean of the quantitative morphological characteristics of M2 generation of the two soybean varieties (Giza111 and Crawford soybeans) after exposure to different doses of gamma-irradiation.

\begin{tabular}{|c|c|c|c|c|c|c|c|c|}
\hline \multicolumn{9}{|c|}{ Soybean variety } \\
\hline \multirow[b]{2}{*}{ Character } & \multicolumn{4}{|c|}{ Giza111 } & \multicolumn{4}{|c|}{ Crawford } \\
\hline & Control & $\begin{array}{c}150 \\
\text { Gray }\end{array}$ & $\begin{array}{c}200 \\
\text { Gray }\end{array}$ & $\begin{array}{c}250 \\
\text { Gray }\end{array}$ & Control & $\begin{array}{c}150 \\
\text { Gray }\end{array}$ & $\begin{array}{c}200 \\
\text { Gray }\end{array}$ & $\begin{array}{c}250 \\
\text { Gray }\end{array}$ \\
\hline Days to flowering & 30 & 36 & 36 & 40 & 28 & 36 & 36 & 0 \\
\hline Days to maturity & 55 & 83 & 80 & 90 & 50 & 64 & 50 & 0 \\
\hline Germination (\%) & 35 & 20 & 40 & 45 & 67.6 & 12.5 & 15 & 7.5 \\
\hline Pod shattering (\%) & 5.9 & 0 & 2.7 & 4.7 & 5.7 & 8.5 & 5 & 0 \\
\hline $\begin{array}{l}\text { Weight of } 100 \text { seeds } \\
(\mathrm{g})\end{array}$ & 13.4 & 12.3 & 14.5 & 14 & 12 & 11 & 10.5 & 0 \\
\hline No. of seeds per plant & 3.1 & 2.6 & 3 & 2.6 & 2.8 & 2.6 & 2.8 & 0 \\
\hline No. of pods per plant & 34 & 34 & 36.1 & 35.1 & 65.6 & 75.4 & 42.5 & 0 \\
\hline Days to flowering & 30 & 36 & 36 & 40 & 28 & 36 & 36 & 0 \\
\hline Days to maturity & 55 & 83 & 80 & 90 & 50 & 64 & 50 & 0 \\
\hline
\end{tabular}

In Giza111 and Crawford M1 plants, seedling height, number of seeds per pod and stem branching, decreased gradually depending on increase in gamma radiation $(150,200$ and $250 \mathrm{~Gy}$ ), the same was found in M2 plants as well. Reduction in seed yield (seeds/plant) in M1 generation was observed in Crawford after exposure to dose $250 \mathrm{~Gy}$. This reduction was in accordance with what have been found by Mehetre et al. (1994) who confirmed that yield reduction was resulting from injury effect in seeds and usually showed inhibitory effects on seeds of angiosperms and gymnosperms (Thapa, 1999). Our results are in line with Sharif et al. (2000), Din et al. (2003), Kon et al. (2007), and Marcu et al. (2013). Comparison of yield (seeds/plant) of the two varieties under study revealed that Giza111 seed yield (seeds/plant) is higher than Crawford seed yield (seeds/plant) in all related doses. These results might be due to stimulating effects of gamma-radiation on activating RNA synthesis or protein synthesis (Kuzin et al., 1976).

In study, the 250 Gy dose had increased slightly some characters like shoot height, number of pods per plant, pod length, percentage of germination, seed length and absence of leaf abnormalities from M1 to M2 generations. The 250 Gy dose in Crawford showed very low percentage of seed germination because the plants with high dose of radiation didn't give mature seeds. This was also reported by Ahmad and Qureshi (1992) in Zea mays L. and Din et al. (2003) in Triticum aestivum L. Our results also showed a decrease in shoot and root length when high gamma radiation dose $(250 \mathrm{~Gy})$ was used. This observation could be correlated with the results obtained by Khalil et al. (1986), who attributed a decreased in shoot and root lengths at higher doses of gamma rays resulted from reduction mitotic activity in meristematic tissues and reduced moisture contents 
in seeds. The decrease in morphological characteristics of various crops has already reported by (Thimmaiah et al., 1998; Khan and Qureshi, 2001; Al-Salhi et al., 2004 and Toker et al., 2005), which supports the present investigation.

\section{Protein analysis}

After treatment of the two soybean varieties (Giza 111 and Crawford) with different doses of gamma rays $(150,200$ and $250 \mathrm{~Gy})$, variation in protein banding patterns was studied using SDS-PAGE for each variety and in treated seeds and the two following generations (M0, M1 and M2) (Fig. 1a \& 1b and Table 3).

All living organisms are normally affected with radiation, which is a crucial environmental stress. Particularly, cellular components are usually affected with the ionizing radiation and thus inducing biochemical and molecular changes in plants (Vanhoudt et al., 2010). Evaluation of these biological changes is very important as they occur through such biochemical changes. Ionizing radiation produces $\mathrm{OH}^{\circ}$ and $\mathrm{O}^{*}$, which induced damage in DNA and proteins by breaking chemical bonds in such biomolecules (Roldán-Arjona and Ariza, 2009; Esnault et al., 2010; Somosy, 2010 and Çelik et al., 2014).

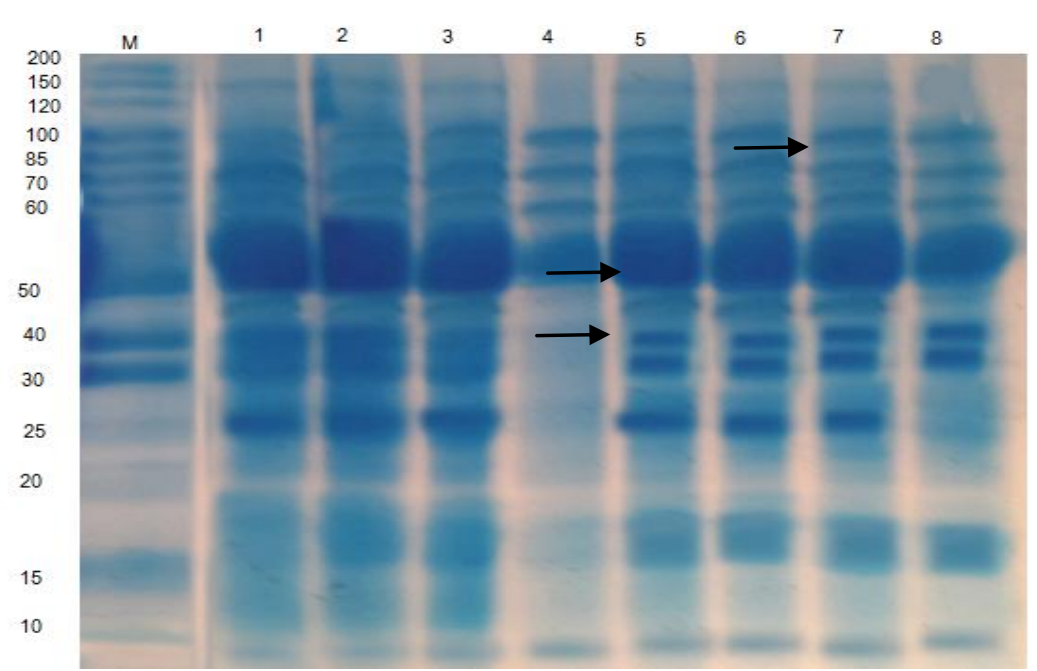

Fig. 1a. Protein profiles of M1 generation seeds of the two soybean varieties (Giza111 and Crawford) using SDS-PAGE technique. 1=Giza111 control, 2= Giza111 treated with 150 Gray, 3= Giza111 treated with 200 Gray, 4= Giza111 treated with 250 Gray, 5= Crawford control, 6= Crawford treated with 150 Gray, 7= Crawford treated with 200 Gray and 8= Crawford treated with 250 Gray. 


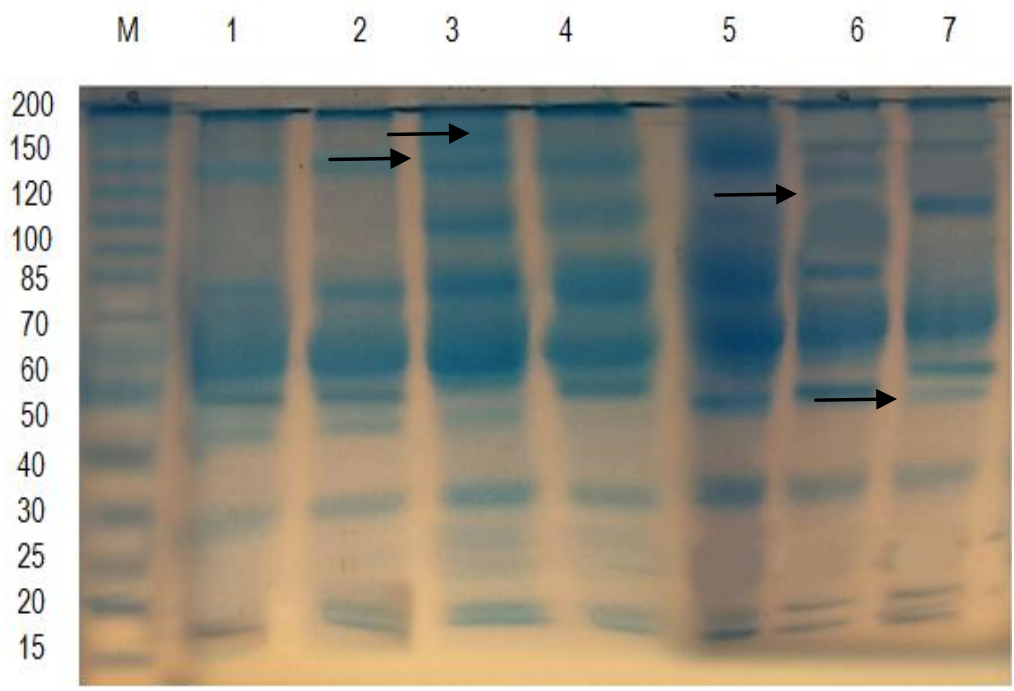

Fig. 1b. Protein profile of M2 generation seeds of the two soybean varieties (Giza111 and Crawford) using SDS-PAGE technique. 1=Giza111 untreated control, 2= Giza111 treated with 150 Gray, 3= Giza111 treated with 200 Gray, 4= Giza111 treated with 250 Gray, 5= Crawford untreated control, 6= Crawford treated with 150 Gray and $7=$ Crawford treated with 200 Gray.

TABLE 3. Summary of the observed protein bands in SDS-PAGE patterns of the M0, M1 and M2 generations of the two soybean varieties (Giza111 and Crawford).

\begin{tabular}{lccc}
\hline \multicolumn{1}{c}{ Generation } & \multicolumn{2}{c}{ Soybean variety } \\
\hline Type of band & Giza111 & Crawford \\
\hline M0 & $\mathbf{M}$ & 11 & 11 \\
& $\mathbf{P}$ & $2(16 \mathrm{kDa} / 250 \mathrm{~Gy})$ & $2(16 \mathrm{kDa} / 250 \mathrm{~Gy})$ \\
Total & $\mathbf{U}$ & 0 & $1(37 \mathrm{kDa} / 250 \mathrm{~Gy})$ \\
\hline M1 & $\mathbf{1 3}$ & $\mathbf{1 4}$ \\
& $\mathbf{P}$ & 5 & 9 \\
Total & $\mathbf{U}$ & 7 & 2 \\
\hline M2 & $\mathbf{M}$ & 0 & 0 \\
& $\mathbf{P}$ & 5 & 6 \\
Total & $\mathbf{U}$ & $1(162 \mathrm{kDa} / 200 \mathrm{~Gy})$ & $1(102 \mathrm{kDa} / 150 \mathrm{~Gy})$ \\
\hline
\end{tabular}

$\mathbf{G y}=$ Gray, $\mathbf{M}=$ monomorphic, $\mathbf{P}=$ polymorphic, $\mathbf{U}=$ unique, $\mathbf{M} \mathbf{0}=$ irradiated seeds before planting, $\mathbf{M 1}=$ first mutant generation, $\mathbf{M 2}=$ second mutant generation. 
Total of 35 protein bands were found. Three of which were unique protein bands, one unique band (37 KDa) was found in M0 in Crawford at $250 \mathrm{~Gy}$ treatment. The other two unique bands (102 and $162 \mathrm{KDa})$ were found in M2 generation in Crawford at $150 \mathrm{~Gy}$ and Giza111 at $200 \mathrm{~Gy}$, respectively (Fig. 1a and $1 \mathrm{~b}$; Table 3 ). This clearly indicated that gamma rays have induced changes in gene expression leading to change in types of the translated proteins in the SDS protein profiles of the studied soybean varieties. However, Kiong et al. (2008) reported no significant change in protein profiles after gamma-irradiation.

Interestingly, the results showed that there is an appearance and disappearance of protein bands in the seed protein profiles after exposure to the $\gamma$-radiation (Fig. 1a and 1b). These changes may be caused by denaturation of protein, protein association or deamination as described by Abu et al. (2005). Moreover, the appearance and disappearance of protein bands may be related to environmental stresses that cause changes in gene expressions (Ariraman et al., 2016). It has been found that gamma-radiation produces active species such as hydrated electrons and hydroxyl radicals $\left(\mathrm{OH}^{*}\right)$ by its action on the water molecules, which successively react with the protein molecules as described by Yamamoto (1992). In addition, the chemical changes stimulated by irradiation in proteins include, degradation, cross-linking, disruption of the ordered structure of protein molecules and aggregation of the polypeptide chains caused by oxygen radicals as well (Gaber, 2005).

The results, shown in this study, are in agreement with Lee et al. (2005), who showed that low dose of gamma-irradiation was not effectual in producing of proteins with high molecular weights in soybean. Gamma-radiation at low dose caused slight breakdown of polypeptide chains and therefore, less formation of high molecular weight proteins. In case of higher gamma doses (200 and 250 $\mathrm{Gy})$, there were cross-linked products of the degraded protein molecules that could not penetrate the PAGE gel (Fig. 1b).

\section{ISSR analysis}

DNA-based makers are the most reliable tools for evaluating the genetic variation because they are not influenced by environmental conditions. ISSR is a widely-used technique for assessing mutations in DNA sequences, which are induced by mutagens such as gamma radiation. Mudibu et al. (2011) showed that ISSR is a useful marker type that used for identifying polymorphisms in DNA sequences. In this study, five primers gave a total 45, 38 and 28 ISSR bands in M0, M1 and M2, respectively. 25, 18 and 16 of which were polymorphic in M0, M1 and $\mathrm{M} 2$, respectively, 4 were unique bands and 19, 18 and 16 were monomorphic bands in M0, M1 and M2, respectively. The primer HB14 amplified 6 DNA bands, 2 were unique bands ( $895 \& 1050 \mathrm{bp}$ ), both in M1 generation of Giza111 at 150 Gy, while primer 844 and 862 amplified only one unique band both found in M0 Giza111 control. They have a molecular weight of 888 and $900 \mathrm{bp}$, respectively. Although, UBC-827 amplified the highest number of bands (7 ISSR bands in M0) no unique bands were found (Fig. $2 \mathrm{a}$ and $2 \mathrm{~b}$ ).

Egypt. J. Bot. 57, No. 1 (2017) 


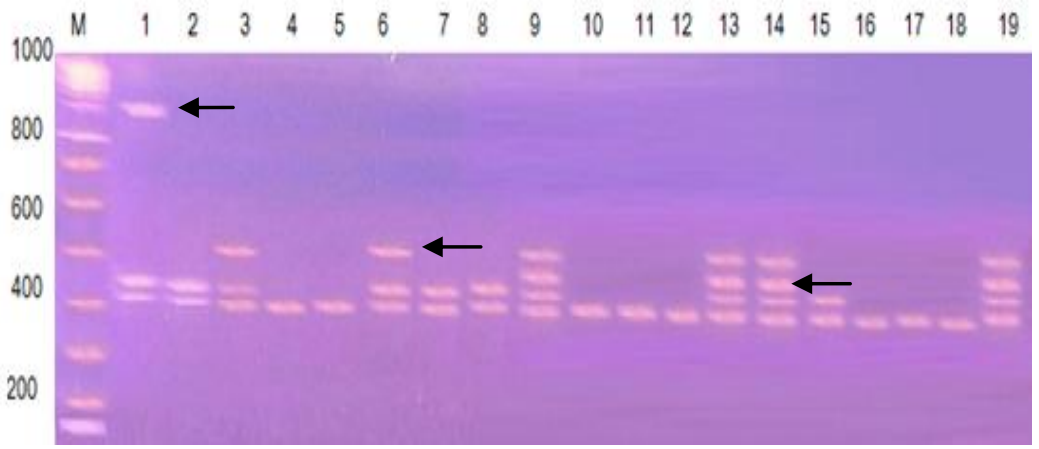

Fig 2a. ISSR banding patterns of M0, M1 and M2 generations of the two soybean varieties (Giza111 and Crawford) using 844 primer. 1=Giza111 control. From 2 to 4 are Giza111 Mo treated with 150, $200 \& 250$ Gray, respectively. $5=$ Crawford control. From 6 to $8=$ Crawford M0 treated 150, $200 \& 250$ Gray, respectively. From 9 to $11=$ Giza111 M1 of M0 treated with 150, 200 \& 250, respectively. From 12 to $14=$ Crawford $M 1$ of $M 0$ treated with 150, 200 \& 250 Gray, respectively. From 15 to $17=$ Giza111 M2 of M0 treated with $150,200 \& 250$ Gray, respectively. From 18 to $19=$ Crawford M2 of Mo treated with $150 \& 200$ Gray, respectively.

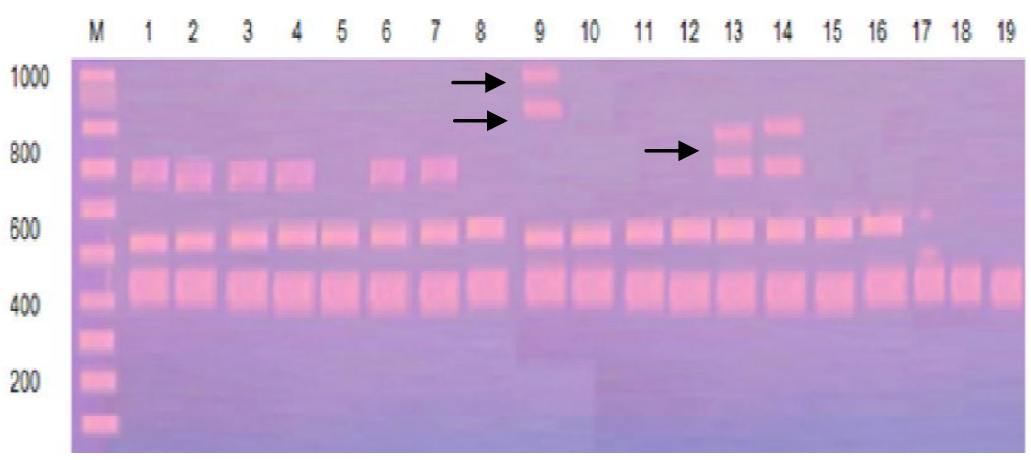

Fig. 2b. ISSR banding patterns of M0, M1 and M2 generations of the two soybean varieties (Giza111 and Crawford) HB14 primer. 1=Giza111 control. From 2 to 4 are Giza111 M0 treated with $150,200 \& 250$ Gray, respectively. 5= Crawford control. From 6 to 8= Crawford M0 treated 150, 200 \& 250 Gray, respectively. From 9 to 11= Giza111 M1 of M0 treated with 150, 200 \& 250 , respectively. From 12 to $14=$ Crawford M1 of M0 treated with 150, 200 \& 250 Gray, respectively. From 15 to $17=$ Giza111 M2 of M0 treated with 150, 200 \& 250 Gray, respectively. From 18 to 19= Crawford M2 of M0 treated with 150 \& 200 Gray, respectively. 
Disappearance of ISSR bands in some M1 and M2 plants (Fig. 2a and 2b; Table 4) could be referred to damages of DNA like single or double-strand breaks, modified bases, oxidized bases, and bulky adducts. In addition, DNAprotein cross links, point mutations and rearrangement of chromosomes induced by gamma irradiation (Ginchner et al., 2008 and Abhay Raj et al., 2014). Moreover, it has been shown that free radicals interact with biomolecules as DNA and remove electrons from them, which in turn causes damage to both structure and activity of the DNA. During ISSR amplification, as Taq polymerase reaches a DNA damage, there could be a blockage by potential dissociation of the enzyme-DNA, which will cause the loss of ISSR bands. However, the appearance of new bands could be related to the effect of mutation instead of DNA damage (Atienzar et al., 2006).

Yoko et al. (1996) have examined the effect of gamma-irradiation on the genomic DNA of corn, soybean and wheat plants. Their results showed that the large strands of DNA were broken into small strands at low irradiation dose. However, small and large DNA strands were broken at higher irradiation doses. Moreover, Kahrizi et al. (2012) showed that when gamma doses were increased, the nuclear DNA content was decreased in all the genotypes studied. Treating plants with highest doses of gamma rays resulted in the highest decrease in content of genomic DNA. Similarly, the appearance or disappearance of bands under gamma irradiation might be considered as molecular markers for radiation processes (Hussein, 2012). It has been exhibited that effects of gamma-rays on ISSR fingerprinting might be connected to structural rearrangements in DNA caused by different types of DNA damages (Mejri et al., 2012) (Fig. 2a and 2b; Table 4).

\section{Conclusion}

Applying of gamma radiation has a reduction effect on yield and other morphological characteristics of two soybean varieties. This was clear particularly with the high gamma-ray doses. In addition, gamma-radiation at low dose caused slight breakdown of polypeptide chains and therefore, less formation of high molecular weight proteins. Furthermore, there was an appearance and disappearance of protein bands in the seed protein profiles after exposure to the $\gamma$-radiation as well as in ISSR profiles, which might be caused by different types of DNA damages.

Acknowledgment : The authors are grateful to the STDF and to Prof. A. Badr, the PI of the STDF project No. 4218, who made facilities available at the Genetics lab, Botany Department, Tanta University. 
TABLE 4. Summary of amplified ISSR fragments using five selected ISSR primers in the M0, M1 and M2 generations of the two soybean varieties (Giza111 and Crawford).

\section{Soybean variety}

Giza111 Crawford

\begin{tabular}{|c|c|c|c|c|c|c|c|c|c|c|c|}
\hline Generation & $\begin{array}{c}\text { Type of } \\
\text { band }\end{array}$ & 844 & 862 & HB10 & HB14 & UBC-827 & 844 & 862 & HB10 & HB14 & UBC-827 \\
\hline \multirow[t]{3}{*}{ M0 } & M & 1 (419 bp) & 1 (452 bp) & $1(269 \mathrm{bp})$ & 3 & 3 & 2 & 1 (452 bp) & 1 & 2 & 4 \\
\hline & $\mathbf{P}$ & 2 & 4 & 4 & 0 & 4 & 1 & 2 & 4 & 1 & 3 \\
\hline & $\mathbf{U}$ & $1(888 \mathrm{bp})$ & $1(900 \mathrm{bp})$ & 0 & 0 & 0 & 0 & 0 & 0 & 0 & 0 \\
\hline Total & & 4 & 5 & 5 & 3 & 7 & 3 & 3 & 5 & 3 & 7 \\
\hline \multirow[t]{3}{*}{ M1 } & $\mathbf{M}$ & 1 & 2 & $(269 \mathrm{bp}) 1$ & 2 & 3 & 1 & 1 & 2 & 2 & 3 \\
\hline & $\mathbf{P}$ & 3 & 0 & 4 & 0 & 2 & 3 & 3 & 0 & 2 & 1 \\
\hline & $\mathbf{U}$ & 0 & 0 & 0 & 2 & 0 & 0 & 0 & 0 & 0 & 0 \\
\hline Total & & 4 & 2 & 5 & 4 & 5 & 4 & 4 & 2 & 4 & 4 \\
\hline \multirow[t]{3}{*}{ M2 } & $\mathbf{M}$ & 1 & 2 & $1(269 \mathrm{bp})$ & 1 & 3 & 1 & 3 & 1 (269 bp) & 1 & 3 \\
\hline & $\mathbf{P}$ & 1 & 2 & 3 & $\begin{array}{c}2(1050 \& 895 \\
b p / 150 \mathrm{~Gy})\end{array}$ & 1 (949 bp) & 3 & 3 & 0 & 0 & 1 \\
\hline & $\mathbf{U}$ & 0 & 0 & 0 & 0 & 0 & 0 & 0 & 0 & 0 & 0 \\
\hline Total & & 2 & 2 & 4 & 3 & 4 & 4 & 3 & 1 & 1 & 4 \\
\hline
\end{tabular}

$\mathbf{G y}=$ Gray, $\mathbf{M}=$ monomorphic, $\mathbf{P}=$ polymorphic, $\mathbf{U}=$ unique, $\mathbf{M} \mathbf{0}=$ irradiated seeds before planting, $\mathbf{M 1}=$ first mutant generation, $\mathbf{M} \mathbf{2}=$ second mutant generation. 


\section{References}

Abhay, R., Sharad, K., Izharul, H. and Mahadeo, K. (2014) Detection of tannery effluents induced DNA damage in mung bean by use of random amplified polymorphic DNA markers. ISRN Biotechnology, 23, 72-76.

Abu, J., Kales, M., Kwaku, G., Duodu, G. and Amanda, M. (2005) Functional properties of cowpea (Vigna unguiculata Walp) flour and pastes as affected by gamma irradiation. Food Chemistry, 93, 103-111.

Addai, I.K. and Safo-Kantanka, O. (2006) Effect of 60C gamma irradiation on storability of soybean seed. Asian Journal of Plant Science, 5 (3), 221-285.

Afify, A. and Shousha, M.A. (1988) Effect of low-dose irradiation on soybean protein solubility, trypsin inhibitor activity and protein patterns separated by polyacrylamide gel electrophoresis. Journal of Agriculture and Food Chemistry, 36(4), 810-813.

Ahmed, S. and Qureshi, S. (1992) Comparative study of two cultivars Zea mays L. after seed irradiation. Sarhad Journal of Agriculture, 8, 441-447.

Al-Salhi, M., Ghannam, M.M., Al-Ayed, M.S., El-Kameesy, S.U. and Roshdy, S. (2004) Effect of gamma irradiation on the biophysical and morphological properties of corn. Nahrung , 48(2), 95-98.

Ambavane, A.R., Sawardekar, S.V., Sawantdesai, S.A. and Gokhale, N.B. (2015) Studies on mutagenic effectiveness and efficiency of gamma rays and its effect on quantitative traits in finger millet (Eleusine coracana L. Gaertn). Journal of Radiation Research and Applied Sciences, 8(1),120-125.

Ariraman, M., Bharathi, T. and Dhanavel, D. (2016) Studies on the effects of mutagens on cytotoxicity behavior in pigeon pea (Cajanus cajan (L.) Millsp) Var. CO-7. Journal of Applied and Advanced Research, 1(1), 25-28.

Atienzar, F. and Jha, A.N. (2006) The amplified polymorphic DNA (RAPD) assay and related techniques applied to genotoxicity and carcinogenesis studies": A critical review. Mutation Research, 613,76-102.

Badr, A., El-Shazly, H.H. and Halawa, M.M. (2014)a Cytological effects of Gamma radiation and its impact on growth and yield of M1 and M2 plants of cowpea cultivars. Cytologia ,79 (2), 195-206.

Badr, A., Sayed-Ahmed, H.I., Hamouda, M., Halawa, M. and Elhiti, M. (2014)b Variation in growth, yield and molecular genetic diversity of M2 plants of cowpea following exposure to gamma radiation. Life Science Journal , 11 (8), 10-19.

Çelik, Ö., Cimen, A. and Zekiye, S. (2014) Response of soybean plants to gamma radiation: Biochemical analyses and expression patterns of trichome development. Plant Omics Journal , 7(5), 382-391.

Egypt. J. Bot. 57, No. 1 (2017) 
Din, R., Khan, M.M., Qasim, M., Jehan, S. and Khan, M.M.I, (2003) Induced Mutability Studies in three Wheat (Triticum aestivum L.) Varieties for Some Morphological and Agronomic Characteristics. Asian Journal of Plant Sciences, 17 (2), 1179-1182.

Esnault, M.A., Legue, F. and Chenal, C. (2010) Ionizing radiation: Advances in plant response. Environmental and Experimental Botany, 68, 231-237.

Gaafar, R.M., Hamouda, M. and Badr, A. (2016) Seed coat color, weight and eye pattern inheritance in gamma-rays induced cowpea M2-mutant line. Journal of Genetic Engineering and Biotechnology, 14, 61-68.

Gaber, M. (2005) Effect of $\gamma$-irradiation on molecular properties of bovine serum albumin. Journal of Bioscience and Bioengineering, 100, 203-206.

Ginchner, T., Zindar, I. and Szakova, J. (2008) Evaluation of DNA damage and mutagenicity induced by lead in tobacco plants. Mutation Research, 652, 186-190.

Hamideldin, N. and Eliwa, N.E. (2015) Gamma irradiation effect on growth, physiological and molecular aspects of mustard plant. American Journal of Agriculture Science, 2(4), 164-170.

Hanafiah, D.S., Yahya, T.S. and Wirnas, D. (2010) Induced mutations by gamma ray irradiation to Argomulyo soybean. Biosciences, 2(2), 121-125.

Hegazi, A.Z. and Hamideldin, N. (2010) The effect of gamma irradiation on enhancement of growth of Okra [(Abel-moschus esculentus (L.) Moench] and associated molecular changes. Journal of Horticulture and Forestry, 2(3), 38-51.

Hussein, O.S. (2012) Protein electrophoresis and DNA in herbs produced from irradiated Ambrosia maritima seeds grown under soil salinity and their resistance to insect. American Journal of Plant Physiology, 7, 261-268.

Kahrizi, Z.A., Kermani, M.J. and Amiri, M. (2012) Effect of gamma rays on nuclear DNA content in different rose genotypes. International Research Journal of Applied and Basic Sciences, 3(6), 1155-1160.

Khalil, S.J., Rehman, S., Afridi, K. and Jan, M.J. (1986) Damage induced by gamma irradiation in morphological and chemical characteristics of barley. Sarhad Journal of Agriculture, 2, 45-54.

Khan, M.R. and Qureshi, A.S. (2001) Quantitative variations induced by gamma irradiation and gibberellic acid in M1 generation of chick pea. Sarhad Journal of Agriculture, 17(3), 367-372.

Kiong, A., Grace, L, Hussein, S. and Harun, A. (2008) Physiological responses of Orthosiphon stamineus plantlets to gamma irradiation. American-Eurasian Journal of Sustainable Agriculture, 8(2), 135-149. 
Kon, E., Ahmed, O.H., Saamin, S. and Ab.-Majid, N.M. (2007) Gamma radiosensitivity study on long bean (Vigna sesquipedalis). American Journal of Applied Sciences, 4(12), 1090-1093.

Kuzin, A.M., Vagabova, M.E. and Revin, A.F. (1976) Molecular mechanisms of the stimulating action of ionizing radiation on seeds. 2. Activation of protein and high molecular RNA synthesis. Radiobiologiya, 16, 259-261.

Laemmli, U.K. (1970) Cleavage of structural proteins during the assembly of the head of bacteriophage T4. Nature, 227, 680-685.

Lima, K., Souza, C., Godoy, R., Franca, T. and Lima, A. (2011) Effect of gamma irradiation and cooking on cowpea bean grains (Vigna unguiculata L. Walp). Radiation Physics and Chemistry, 80 (9), 983-989.

Marcu, D., Damian, G., Cosma, C. and Cristea, V. (2013) Gamma radiation effects on seed germination, growth and pigment content, and ESR study of induced free radicals in maize (Zea mays). Journal of Biological Physics, 39(4), 625-634.

Mehetre, S.S., Mahajan, C.R. and Dhumal, P.M. (1994) Effect of different doses of gamma irradiation on germination and survival of soybean. Soybean Genetics Newsletter, 21, 108-112.

Mejri, M., Mabrouk, Y., Voisin, M., Delavault, P., Simier, P., Saidi, M. and Belhadj, O. (2012) Variation in quantitative characters of faba bean after seed irradiation and associated molecular changes. African Journal of Biotechnology, 11(33), 8383-8390.

Melki, M. and Dahmani, T. (2009) Gamma irradiation effects on durum wheat (Triticum durum Desf.) under various condition. Pakistan Journal of Biological Sciences, 12, $1531-1534$

Mudibu, J., Nkongolo, K.K.C., Mehes-Smith, M. and Kalonji-Mbuyi, A. (2011) Genetic analysis of soybean genetic pool using ISSR marker: effect of gamma radiation on genetic variability. International Journal of Plant Breeding and Genetics, 5, 235-245.

Patil, V.P., Raut, V.M. and Halvnkar, G.B. (1985) Induced variation in soybean variety Kalitur. Biovigyanam, 11, 149-155.

Plesnik, S. (1993) The evaluation of some quantitative traits in M1 generation in soybean after laser emission and ethylene imine treatment. Acta facultatis rerum naturalium universitiatis comenianae, Genetica et biologia molecularis, 24-25, 105-113.

Rahman, S.M., Takagi, V., Kubota, K., Miyamoto, K. and Kawakita, V. (1995) High stearic acid soybean mutant induced by X-ray irradiation. Bioscience, Biotechnology, and Biochemistry, 59, 922-933.

Roldán-Arjona, T. and Ariza, R. (2009) Repair and tolerance of oxidative DNA damage in plants. Mutation Research, 681, 169-179.

Egypt. J. Bot. 57, No. 1 (2017) 
Schum, A. (2003) Mutation breeding in ornamentals and efficient breeding method. Acta Horticulturae, 612, 47-60.

Sharif, A., Khan, M.R. and Hussain, S.A. (2000) Effect of gamma radiation on certain characters of Gossypium hirsutum L. Pakistan Journal of Agriculture Research, 16(2), 114-119.

Smith, K. and Huyser, J. (1987) World distribution and significance of soybean. In: JR Wilcox [ed.], "Soybeans: Improvement, Production, and Use", 1-22. $2^{\text {nd }}$ ed. Amer. Soci. Agron., Madison, Wisconsin.

Somosy, Z. (2010) Radiation response of cell organelles. Micron, 31, 165-181.

Song, H.S. and Kang, S.Y. (2003) Application of natural variation and induced mutation in breeding and functional genomics: papers for international symposium; current status and future of plant mutation breeding. Korean Journal of Breeding Science, 35(1), 24-34.

Thapa, C. (1999) Effect of acute exposure of gamma rays on seed germination of Pinus kesiya Gord and and P. wallichiana A.B. Jacks. Botanica Orientalis Journal of Plant Science, 120-121.

Thimmaiah, S.K., Mahadevu, P., Srinivasappa, K.N. and Shankra, A.N. (1998) Effect of gamma irradiation on seed germination and seedling vigor in Cowpea [Vigna unguiculata (L.) Walp.]. Journal of Nuclear Agriculture and Biology, 27(2), 142-145.

Toker, C., Uzun, B., Canci, H. and Ceylan, F. (2005). Effects of gamma irradiation on the shoot length of Cicer seeds. Radiation Physics and Chemistry, 73(6), 365-367.

Vanhoudt, N., Vandenhove, H., Horemans, N., Wannijn, J., Hees, M., Vangronsveld, J. and Cuypers, A. (2010) The combined effect of uranium and gamma radiation on biological responses and oxidative stress induced in Arabidopsis thaliana. Journal of Environmental Radioactivity, 101, 923-930.

Yamamoto, O. (1992) Effect of radiation on protein stability. In: TJ Ahern, Manning MC [Eds.], "Stability of Protein Pharmaceuticals", pp. 361-419. Plenum press, New York, USA.

Yoko, K., Aya, M., Hiromi, I., Takashi, Y. and Kukio, S. (1996) Effect of gamma irradiation on cereal DNA investigated by pulsed-field gel electrophoresis. ShokuhinShosha, 31, 8-15.

Yu, X., Wu, H., Wei, L.J., Cheng, Z.L., Xin, P., Huang, C.L., Zhang, K. and Sun, Y.Q. (2007) Characteristics of phenotype and genetic mutations in rice after spaceflight. Advanced Space Research 40(4), 528-534.

(Received 2/12/2016;

accepted 20/1/2017)

Egypt. J. Bot. 57, No. 1 (2017) 


\title{
تأثير جرعات مختلفة من أثنعة جاما على الصفات الظاهرية والجزيئية لصنفين مصريين من فول الصويا جاميا
}

\author{
رضا محمـد جعفر ، عادل رمضـان الثنشـوري ، مروة حمـودة و ربنا ديـاب
}

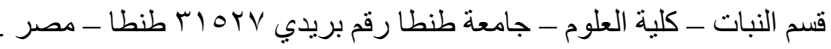

\begin{abstract}
يعتبر فول الصويا هو أحد أهم المحاصيل غذائياً وتجارياً. في هذه الدراسة نم

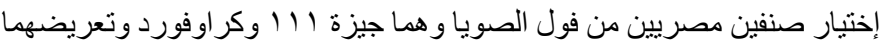

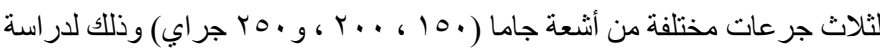

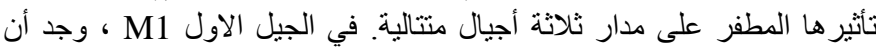

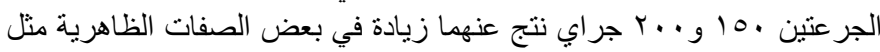

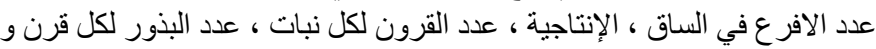

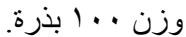

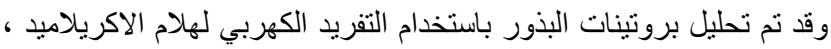

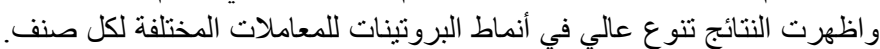

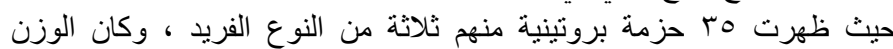

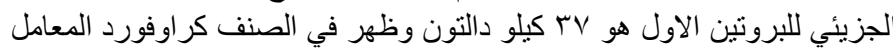

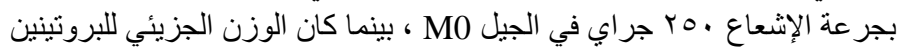

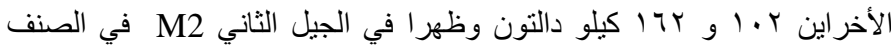

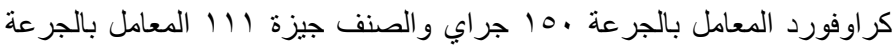

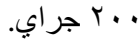

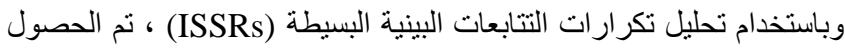

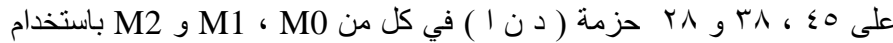

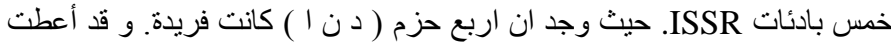

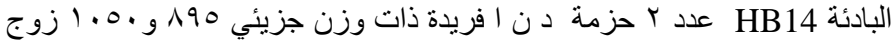

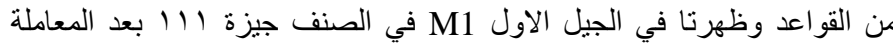

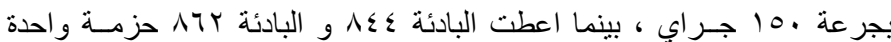

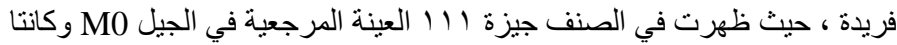

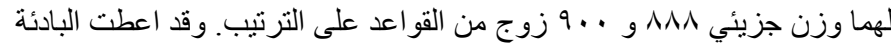

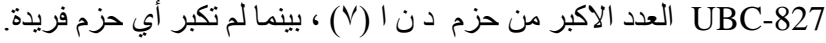

